\title{
REVIEW S.
}

A Clinical Atuas of Venereal axd Skin Diseabes, Ixcldoing Diagnosis, Progiosis, aso Treatyent. By Ronent W. Taylon, A.M., BI. D., Surgeon to Charity Hospital, New York, etc. Illustrated with one hundred and ninety-two figures, many of them life-size, on fifty-eight benutifully colored plates, also maay lnrge and carefully execnted engrarings through the text. Parts I. aad II. Veaereal Diseases. Philadelphia: Lea Brothers and Co., 1888.

A Distwodraned American artist bas Intely declared that no one can by the aid of words alone go graphienlly describe a picture to even the most skilful artist, that the latter can, without cther knowledge, make even the fuiutest attempt at a reproduction of the original. Here one may estimate the disadvantages of the didactic over the clinical methods of teaching medicine. There are few cliuical teachers who surpass in advantages the best portraits of disease. It is a marvellous matter that the Atlases are not preferred, as they should be, above all the trentises. It ig, bowever, true that they are not. The Atlns before us furnishes a fuud of information of the most practical sort that is quite inaccessible to one who has not enjoyed s large clinical experience and who is compelled to rely on the printed page for the knowledge required in venereal and cutnneous disorders.

In this nutter of eye-instruction as compared with enr-instruction, the snvage is in ndvance of the scientist. Mr. Edouard Muybridge has plotograpbed an Indian blanket sent by LaFayette to France in the last century, on which horses nre represented with the anatomical accuracy displayed on the frieze of the Parthenon, and recently demonstrated to be faithful to nature by Mr. BLuybridge's remarkahle photographs taken iustantaneously of animals in motion. One careful study of a faithful portrait of disease is often worth more than reading a lenrnod essay on the same theme. The former is ble the unconsciously nequired farniliarity with the features of an acquaintance; the latter, like reading his biography.

Dr. Taylor's admirnble Atlas is so suggestive on many of the themes that interest the modern student of medicine, that one might readily be tempted to deliver a clinical lecture on the basis of the well.drawn figures and carefully tinted illustrations which its pages spread before the observant eye. Here are exhibited nlmost every one of the results of the pathological processes occurring in the skin and the mucous aurfaces of the body. There is scarce $n$ figure in any plate that does not surpass, in value to the studeat, all the writiags of Boerbanve and some of the more modern treatises by less distinguished men. It is ensy to underatanil, as we glance at the portraits thus faithfully drawn, why Mr. Seymour Huden was so earnest in impressing upon bis students in surgery the importance of acquiriag the nrt of drawing with a vies to fixing more iadelibly ia the memory tbe fentures of external disease. "The 
modern Remhrandt," as he bas been called, confesses to having himself first engaged in his favorite work of etching merely as an aid to his surgical work.

The illustrations before us nre new nnd nld, nnd we are in no fear of contradiction when recommending the nld with the new. Just in proportion as the old are faithful, are they as good as, or hetter than, the new. It is now nearly a balf century since Rnyer first gave his fiue plates of skin and venerenl diseases th the ecientific world, nnd was followed by Trüstedt and Behrend, who, with Dr. Tnylor's cormendable foresight, a railed themselves nf the hest tbat had then preceded. Fifty years in one sense, is not $\mathrm{n}$ long period; but in anotber it constitutes a cycle, as, fir example, in measuring the progress of the world's advance in knowledge. When Rayer first published his plates, therc was no clectric telegraph in operntion; nnd the entire modern system of postal transmission wae not yet conceived in the fertile brain of Sir Rowland Hill. The wluole pitiful carecr of tbe "Little Napoleon" was.yet to be n part of historg. The works then written nnd studied as authoritative in medicine are now, Eave for the collector nf medical bric-a-brac, worth simply the price of old paper per pound! And yet, wonderful to relate iu comparison, but vet only truth to tell (for the truth of to-day is the truth of to-morrow if only it be a real trutb), Rayer's faithful plates of externnl disensc, copied, quaint costumes nnd all, by Trüstedt and Behrend, are not shown to be false by the brillinnt portraits and striking illustrations of disease furnished by nur latest author! If one looks with care, for csample, nt the exccllent representation here given (Part II., Plute XIV., Fig. 1) nf the smnll pustular syphilide, he will find there only the same syphilis portrnyed by the eminent Frenchman $\Omega$ half ccntury bcfore! But if he stidies it closely and with the careful scrutiny of the thedical nrtist, he will recognize n more definite purpose to cxhibit the exact sluadc of color, size, pustular npex, nnd physiognomy of the iuclividual lesion, with a pre-Rnphaelite minuteness of detail, the general effect being to produce a picture of the skin in disease which can scarcely be surpassed iu its ralue when nnc considers the nceds of the physician.

Dr. Taylor's Atlas can be well commended to the profession as a credit to American medical literature. The publishers deserve special praise for the elcgance of the typography nnd the care taken to produce the colored plates with thic uost nrtistic results.

J. N. H.

Klisik ner Vernautsgskraxkmeitex. Voa Dr. C. Ewaln, Professor e. o. an der Universität, dirigirender Arzt am Augusta Hospital zu Berlin. II. Die Knaxfgeitex nes Magess. Berlin, August HirschwaJd, 1888.

Diseases of Digejtiox. By Dr. C. Evald. Il. TaE Disedseg of the STOMACH.

Tris work occupies the middle space in $\mathbf{n}$ series of three of which the first, the Phiysiology of Digestion, has nlready nppesred, wbile the last,

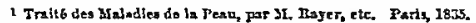

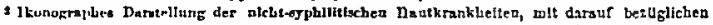

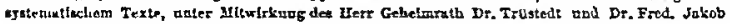
Behrevd, LeipzlE, 1830. 